\title{
Hybrid wood-polymer composites in civil engineering
}

\author{
Гибридные древесно-полимерные композиты \\ в строительстве
}

\author{
A.N. Ponomarev, \\ A.S. Rassokhin, \\ Peter the Great St. Petersburg Polytechnic \\ University, St. Petersburg, Russia
}

\author{
Канд. техн. наук, профессор \\ А.Н. Пономарев, \\ аспирант А.С. Рассохин, \\ Санкт-Петербургский политехнический \\ университет Петра Великого, г. Санкт- \\ Петербург, Россия
}

\begin{abstract}
Ключевые слова: гибридные древеснополимерные композиты; пропитка; реактопласты; стеклянные, базальтовые, углеродные ленты; внешнее и межслойное армирование; водорастворимые сульфоаддукты нанокластеров углерода (Углерон С); углеродные нанопористые

микроволокна; ЭпоксиПАН
\end{abstract}

Key words: hybrid wood-polymer composites; impregnation; thermosets; glass, basalt, carbon tapes; external and interlayer reinforcing; watersoluble sulfoadducts of the carbon nanoclusters (“Ugleron C"); carbon nanoporous microfibres; EpoxyPAN.

\begin{abstract}
The interest in wood-based materials and structures is increasing every year, and as a result, attempts are constantly being made to modify it, in order to increase mechanical and operational characteristics. In this case the complicating circumstances are the contradiction between the hydrophilic nature of wood and water repellence of the majority of the thermosets that can significantly affect the properties of wooden parts and structures. The paper analyzes the state of research in this area and draws conclusions in favor of methods of wood gradient impregnation with reinforcing water-compatible epoxy thermosets and external as well as interlayer reinforcement of wood structures with high-strength glass-, basalt-, organo- and carbon-fiber ribbons with anisotropic properties. The possibility of modification of water-compatible epoxy polymers by carbon micro- and nanoparticles of new species was also studied. The results of the pilot studies of the wooden details gradient impregnated with the water compatible epoxy compositions modified by sulfoadducts of nanoclusters of carbon ("Ugleron C") and carbon nanoporous microfibers (CNPMF) are given. The possibility and features of external reinforcing of the wooden details by glass ("E" - type fibre), carbon (on the basis of carbon fibers) was considered and the case of the basalt and polyaramid unidirectional tapes was estimated. The technology of the additional strengthening the wooden details by an external membrane from a multifunctional composite water compatible coating - the "EpoxyPAN" was offered. Results of the tests the samples of the wooden details covered with a continuous membrane from "EpoxyPAN" have confirmed the previous assumptions of the prospects of such technology. Thus, the possibility of creation of the hybrid wood-polymer composites (HWPC) of new types is proved and problems of further work are formulated.
\end{abstract}

Аннотация. Интерес к материалам и конструкциям на основе древесины с каждым годом увеличивается, вследствие чего постоянно предпринимаются попытки ее модификации, для того, чтобы повысить механические и эксплуатационные характеристики. Осложняющими обстоятельствами при этом являются гидрофильная природа древесины и гидрофобность большинства реактопластов, способных заметно повлиять на свойства деревянных деталей и конструкций. В работе проведен анализ состояния исследований в этой области и сделаны выводы в пользу методов градиентной пропитки древесины усиливающими водосовместимыми эпоксидными реактопластами и внешнего, а также межслойного армирования древесных конструкций высокопрочными стекло-, базальто-, органо- и углеволокнистыми лентами с анизотропными свойствами. Проведено также изучение возможности модификации водосовместимых эпоксидных полимеров углеродными микро- и наночастицами новых видов. Приводятся результаты экспериментальных исследований деревянных деталей, градиентно пропитанных водосовместимыми эпоксидиановыми и эпоксиноволачными композициями, модифицированными сульфоаддуктами нанокластеров углерода («Углерон С») и углеродными нанопористыми микроволокнами (УНПМВ). Одновременно рассматривается и оценивается Пономарев А.Н., Рассохин А.С. Гибридные древесно-полимерные композиты в строительстве // Инженерностроительный журнал. 2016. № 8(68). С. 45-57. 
возможность и особенности внешнего армирования деталей из древесины стеклянными («Е»стекло), углеродными (на основе углеродных волокон Т-700), базальтовыми и полиарамидными однонаправленными лентами. Предложена технология дополнительного усиления деревянных деталей внешней мембраной из многофункцинального композиционного водосовместимого покрытия «ЭпоксиПАН». Результаты испытаний образцов деревянных деталей, покрытых сплошной мембраной из «ЭпоксипАНа» подтверждают сделанные предположения о перспективности такой технологии. Таким образом, обоснована возможность создания гибридных полимерно-древесных композитов (ГПДК) новых видов и сформулированы задачи дальнейшей работы.

\section{Introduction}

The first impregnating structures increasing not only fire - bioprotective, but also physics and mechanical properties of wood have appeared at the beginning of the XX century. In 1909 the Belgian chemist and the inventor Leo Bakeland have synthesized the first synthetic thermosetting polymer, received at the initial stage of synthesis of phenol formaldehyde resin which called "Bakelit" [1]. A little bit later in Russia its analogs have been synthesized - carbolit [2, 3] (in 1914), and in the early twenties bazilit - antiseptics on the basis of dinytrophenol, possessing the strengthening action [3] which have found broad application in the industry of that time. Bakelite wood was widely used in aircraft industry, shipbuilding, mechanical engineering, etc. and is still applied.

Now the choice of structures for increase of physics and mechanical characteristics of wood is much wider $[4,5]$. In this connection it is necessary to prove criteria of choice of the optimal variants. These criteria can be shared conditionally into two groups: operational and technological. Among technological parameters the most important is the possibility of solving the contradiction between hydrophilic of wood and water repellency of the majority of high-strength polymer compositions.

Table 1. Comparative characteristics of the strongest polymers which can be used for the physics and mechanical modification of wood [6-13]

\begin{tabular}{|c|c|c|c|c|c|c|c|c|}
\hline № & $\begin{array}{c}\text { Type of } \\
\text { polymer }\end{array}$ & $\begin{array}{c}\text { Dencity, } \\
\mathbf{g} / \mathbf{c m}^{\mathbf{3}}\end{array}$ & $\begin{array}{c}\text { Tough- } \\
\mathbf{n e s s} \\
\mathbf{k J} / \mathbf{m}^{2}\end{array}$ & $\begin{array}{c}\text { Pressure } \\
\text { Strength } \\
\mathbf{M P a}\end{array}$ & $\begin{array}{c}\text { Tension } \\
\text { Strength } \\
\mathbf{M P a}\end{array}$ & $\begin{array}{c}\text { Elasticity } \\
\text { module } \\
\mathbf{M P a}\end{array}$ & $\begin{array}{c}\text { Viscosity in } \\
\text { uncured } \\
\text { form, } \\
\mathbf{M P a} \mathbf{c}\end{array}$ & $\begin{array}{c}\text { Brake } \\
\text { Elongation, } \\
\%\end{array}$ \\
\hline 1 & $\begin{array}{c}\text { Phenol- } \\
\text { formaldehyde }\end{array}$ & $1.25-1.38$ & $10-20$ & $90-150$ & $50-100$ & $1800-2300$ & $90-1200$ & $1.2-3$ \\
\hline 2 & Melamine & $1.45-1.6$ & $2.5-6$ & $150-200$ & $55-98$ & $5000-5500$ & $150-1000$ & $0.8-2.9$ \\
\hline 3 & Epoxy & $1.16-1.25$ & $12-25$ & $160-300$ & $80-140$ & $2500-3500$ & $1000-7000$ & $2.5-4.1$ \\
\hline 4 & Epoxy novolac & $1.33-1.47$ & $12-15$ & $120-130$ & $85-93$ & $2000-2700$ & $500-40000$ & $3.8-4.1$ \\
\hline 5 & Polyester & 1.215 & 0.75 & 160 & 65 & 3000 & $900-1000$ & 2.5 \\
\hline 6 & Vinylester & $1.1-1.25$ & $13-24$ & $35-50$ & $90-146$ & $2300-3600$ & $450-750$ & $2.1-15$ \\
\hline 7 & Methacrylate & $1.17-1.2$ & $9-13$ & $120-160$ & $80-140$ & $3000-3500$ & $500-2500$ & $0-0.5$ \\
\hline 8 & $\begin{array}{c}\text { Polyvinyl } \\
\text { alcohol }\end{array}$ & $1.2-13$ & $4-120$ & $24-140$ & $63-120$ & $1400-6000$ & $5-45$ & $0-3$ \\
\hline
\end{tabular}

\section{Derivations from Table 1:}

In spite of the fact that the nomenclature of various synthesized polymers is very big now, the majority of them are almost not applicable for impregnation of the wooden details. The main reasons insufficiently high physics and mechanical and other operational characteristics, and lack of a possibility of creation the water compatible compositions on their basis with high level of penetration. All the thermosetting polymers demanding high temperatures and pressure for it processing are also automatically excluded from the perspective directions also. From all considered and selected options epoxy compositions are of the greatest interest on condition of solution the problem of their water repellency.

One of the technologically attractive opportunities of increasing physics and mechanical characteristics of many thermoreactive polymers is their modification with small amounts of special types of carbon nanoparticles [14-25]. At the same time the possibility to preserve low viscosity of the impregnating structures is supposed to exist and is already proved to considerably improve their physics and mechanical characteristics and increase durability.

Ponomarev A.N., Rassokhin A.S. Hybrid wood-polymer composites in civil engineering. Magazine of Civil Engineering. 2016. No. 8. Pp. 45-57. doi: 10.5862/MCE.68.5 
However, impregnation and polymerization of the impregnating structures themselves cannot provide the highest increase of physics and mechanical characteristics of wood. The required results can be reached by combining impregnation with reinforcement of wood polymers by high-strength polymeric composites on the basis of fabrics and tapes made from "E" - glasses, basalt, carbon and poliaramid fibers. Listed polymer composite materials can have very high physics and mechanical characteristics themselves, but their wide use is seriously limited by its high price. Cheaper analogs with the lower cost but comparable properties are essential for practical application in construction. Results of comparison of the conditional prices for the unit mass of composite production for the different types and metal details of the same sizes are given in Figure 1.

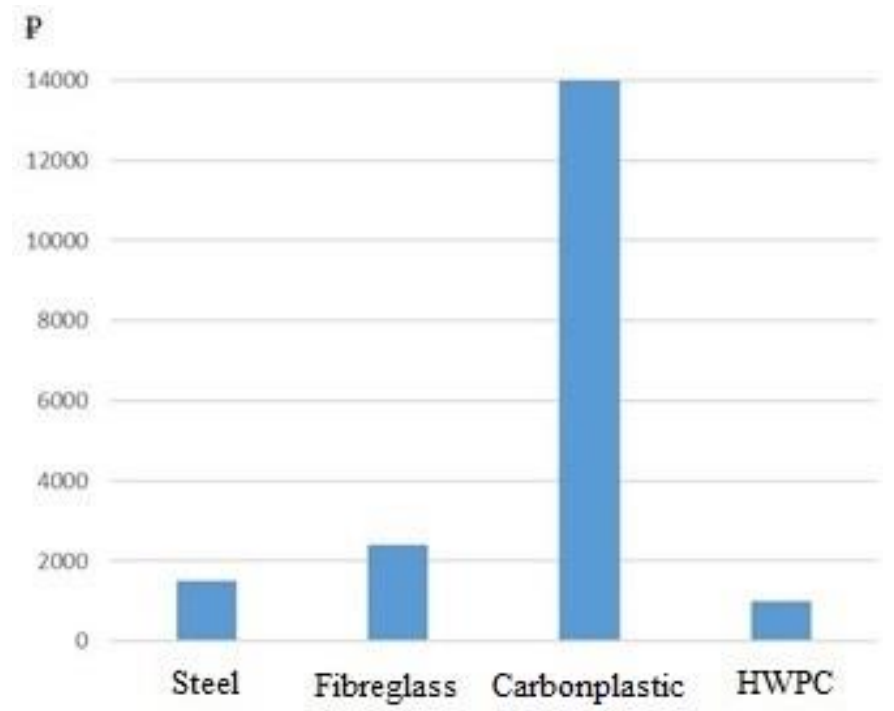

Figure 1. Comparative conditional price of all-metal and composite details with the size $30 \times 100 \times 1000 \mathrm{~mm}$

Prospects of developments and production of hybrid wood polymeric composites (HWPC) follow from this comparison evidentially. However, the problem of increasing the HWPC physics and mechanical characteristics to the level of the corresponding values received for monolithic carbonplastics and separate types of fibreglasses remains unsolved.

In construction the method of external reinforcing of various details by carbon fabrics have been successfully proved in practice. This method has been applied to strengthening of reinforced concrete structures for a long time [26]. The same approach brings possibilities of the strengthening the structures on the basis of wood and develop the new types of HWPC.

Such attempts were made numerously. In 1965 the American engineer Evangelos John Biblis has reported to discover potential possibility to use flat fittings from fiber glass for strengthening wood details [27]. But at that time it was difficult to carry out complex tests due to the lack of the industrial materials suitable for external reinforcement of wood and high-quality glues.

Nearly 30 years later, in the 1990-th this topic has been raised again by group of scientists N. Plevris, N. Deskovic and T. Triantafillou [28-31], as the industrial market featured a wide choice of reinforcing materials and high-quality glues. For example, the unidirectional carbon tapes $0.55-0.77 \mathrm{~mm}$ thick were pasted as a way to reinforce wooden beams externally by means of epoxy glue. Tests have shown the increase in durability by $20-40 \%$ comparing to rather similar beams without external reinforcing. There was no rupture of the carbon tapes, however there was a cohesive destruction of wood or destruction of glue connection. H. Dagher [32] arrived at the same results.

The influence of degree of humidity of wood was important [33, 34]. Well dried wood $(5-7 \%$ of humidity) showed better results than a damper one as these cases showed the best adhesion to glue structures of system of external reinforcing. Final durability also depended on the amount of natural defects (knots) on wood preparation [35].

The obvious results of improvement of the strengthened wood structures properties have set up the field of application of composite materials: repairing of the wooden beams [36,37], restoration of monuments of wooden architecture [38-40], bridge building [41, 42]. The area of application defined the best options of external reinforcing or strengthening were developed: reinforcement of all surface [43, 44], bearing surface area [40, 44], places of a break [45], winding [46]. Also there were created and 
investigated options of high-strength materials for external reinforcing: unidirectional carbon tapes or polyaramid fibers (average increasing of the durability was 30-40\%), fiber glass fabrics or basalt tapes (average increasing of the durability was 15-30\%) [29, 38, 43, 45, 47-49].

Reinforcement by the different fibers is possible not only for integral details, but also for improvement of quality of seams of the glued wood [50,51]. Usage of the reinforcement increases durability at a bend for $26-51 \%$ depending on the amount of the reinforcing material and the way of his injection [52]. Usage of carbon fiber or fiberglass cores and lamels for creation of tongue-and-groove connections $[53,54]$ is also shown.

Pretension of carbon tapes in a beam by means of metal anchors can be created in order to reduce a deflection of wooden beams [55].

Economic prospects of implementation of HWPC were considered in the work of F. Taheri, M. Nagaraj and P. Khosravi [56]. These authors observe lower price of HWPC due to mass production and optimization of cross section of details. Undoubtedly postponed economic effect must also appear due to increase of durability of HWPC.

There are also opposite opinions. For example, Y. Kim and K. Harries [57] do not exclude isolated cases of application of hybrid wood and polymeric composites (reconstruction of monuments of wooden architecture, etc.), but exclude mass character as, in their opinion, it will be impossible to increase their bearing ability more than for $40 \%$. Even if external reinforcement will make it possible to resist heavy loads, bearing strain or cohesive destruction of the main body of wood will happen.

The results of the carried-out analysis suggest that it is possible to define the main directions of development of hybrid wood and polymeric composites:

- the choice of optimum materials for impregnation into the precursors of HWPC, the most corresponding on economic, physics and mechanical and operational indicators, capable to considerably increasing the strength of the wood and to give it ability to resist bearing strain and cohesive destruction;

- development of technology for gradient impregnation into the precursors of HWPC with the purpose of improvement of physics and mechanical characteristics and achieving the maximum adhesion to the external reinforcing layer;

- the choice of materials of external reinforcement, the most corresponding on economic, mechanical and operational indicators.

- constructive and technological development the processes of manufacturing the HWPC.

Relatively recently - in year 2000 the results of work on bulk impregnation and the subsequent polymerization of the resins impregnating wood for the increase of physics and mechanical characteristics of wooden details have been published [58]. In this work the bulk impregnation of wood by phenol formaldehyde, melamine and urea-formaldehyde was carried out. These resins after hardening have provided the increase of durability of wood on compression for 33-35\%, on a bend - 12-20\% and increase in the module of elasticity by 5-12\%, though the expense of the impregnating compositions was rather high, which has considerably worsened prime cost indicators. Certain works describe first attempts to use epoxy compositions [59], and also water compatible epoxy compositions [60]. However, the data about the application the water compatible epoxy compositions have modified by some nanoparticles for this purpose are not revealed now in the considered references. It can be considered as a serious gap as injection of carbon micromodifiers of fulleroid type into the water compatible epoxy compositions, furthermore makes it possible to raise dramatically operational resource of this material and to considerably increase durability of the designs created from HWPC that is extremely essential in construction.

\section{Materials and methods}

According to the planned researches, the bending strength of samples of the HWPC compared to samples of raw wood, the standard preparations have been made of timber of coniferous breeds by the sizes of $80 \times 80 \times 1600 \mathrm{~mm}$ and $20 \times 40 \times 800$ with humidity no more than $10-12 \%$ in total of more than 40 pieces for ensuring statistical reliability of the results of the tests. After preliminary drying of industrial wood in a drying chamber within a regular production cycle of a woodworking and production of the standard preparations of the required shape by method of mechanical milling, drying of preparations was continued for about 25 days indoors with the heated floors without access of damp air. Additional drying was necessary to provide the best possible results of tests of template matching made of basic wood without some subsequent processing and also is expedient for the best interaction with samples of Ponomarev A.N., Rassokhin A.S. Hybrid wood-polymer composites in civil engineering. Magazine of Civil Engineering. 2016. No. 8. Pp. 45-57. doi: 10.5862/MCE.68.5 
HWPC with the impregnating structures on a water basis. "E-glass" TC6-11-380-76 has been chosen as the system of external reinforcing differing in the minimum cost, but possessing the acceptable strength variables for experimenting fibreglasses based on T-25 fabric with a calico weave (Amendment 1-12). Preliminary two-phasic processing of the dried-up samples by water-soluble epoxy structure of "EpoxyPAN-primer" TC 23 1253-053-91957749-2011 was carried out in order to improve adhesion of the reinforcing layers of T-25 fabric to wood and the general increase of physical and mechanical characteristics of these samples of HWPC too. The samples were made with a rough of the prepared surface. The possibility to increase the physical and mechanical characteristics of polymer matrices of the composite materials by method of their modification by insignificant amounts of sulfoadducts of carbon nanoclusters ("Ugleron C") [61] and carbon nanoporous microfibers (CNPMF) [62] was studied in order to choose and optimize impregnating and the subsequent glue structures. Modification was made by method of injection of several various concentration of carbon micromodifiers into the hardener with the subsequent careful hashing of the hardener with the micro modifier, the following mixture of a hardener with state standard specification 10587-84 ED-20 epoxy and filling of shapes in the cylindrical shape with a diameter of $40 \mathrm{~mm}$ and a height of $40 \mathrm{~mm}$. 8 samples were made for ensuring the maximum reliability of the test results for each concentration of the micromodifiers. At the determination of pressure strength, it has provided further for all values of concentration the level of sizes of confidential intervals which is not exceeding $5 \%$ is relative to the set confidential probability 0.95 .

After full polymerization of samples was finished, the faces of cylinders were cleaned and samples were located between plates of a hydraulic measuring press WK18 (Figure 2). By the results of the tests schedules of concentration depending on the pressure strength and the amount of the micromodifiers, the optimal meaning of its concentration was determined. This optimal concentration was taken further for introduction into the polymer matrix of the strengthening layer decided on T-25 fabric.

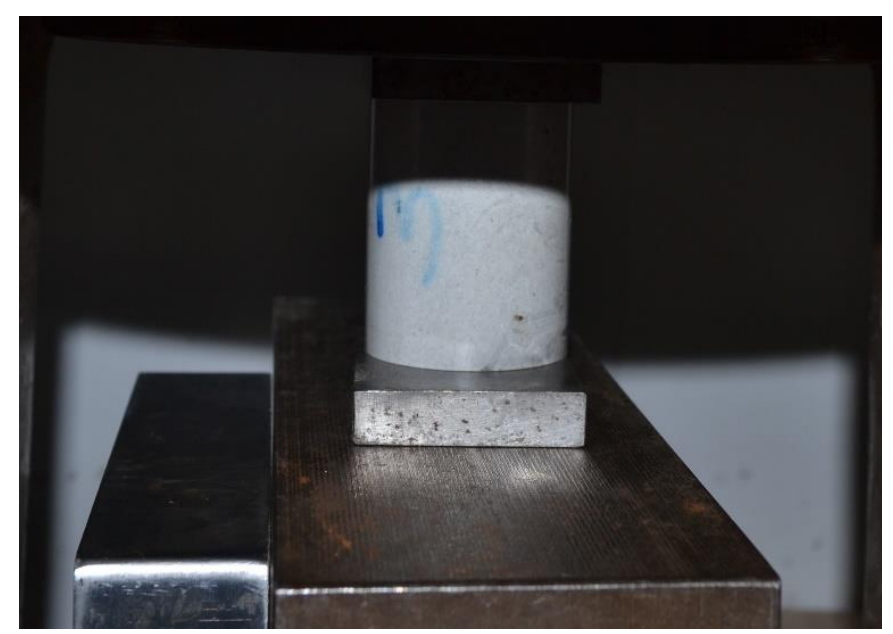

\section{Figure 2. Tests of a sample of the modified polymeric matrix for durability} at compression on the press of WK18

At the subsequent production of test samples of HWPC, the chosen concentration of carbon micromodifiers was entered into the "EpoxyPAN-primer". It was done with the glue for fastening of the strengthening layer by the same way.

After the full polymerization of the impregnating structure which is carried out under normal conditions at a temperature of $30^{\circ} \mathrm{C}$, external reinforcing of preparations by two layers of T-25 (VMP) fabric-78 with a calico weave from "E" - TC 6-11380-76 glasses (with amendment 1-12) method of vacuum molding on two opposite parallel sides of preparations was carried out. As glue structure the composition from 53 \% mass. of epoxy resin ED-20 (Russian State Standard 10587-84), $47 \%$ mass. of water soluble amine hardener was used. The water soluble amine hardener has been modified by carbon nanoporous microfibers (CNPMF) in number of $0.8 \%$ of mass. relatively the mass of the hardener.

Upon completion of polymerization process of glue connection, the continuous membrane from polymer nanocomposite material EpoxyPAN was applied on an external surface of preparations for additional strengthening of HWPC and protection against possible action of hostile environment, water and fire (Fire technical characteristics of EpoxyPAN, according to the existing certificate: G1, If1, Sp1, Fo2, T1). Drawing was made by a pneumatic method by means of the textural sprayer the LC-02 brand PRAKTIKA Ltd company. 
The first stage of examination of test samples of HWPC for durability on stretching at a bend included tests of small-sized samples of HWPC the sizes $20 \times 40 \times 800$ and control of the row wooden models of comparison of the same sizes on a three-point bend. Tests were carried out in accordance with Russian State Standard 16483.3-84. on a hydraulic press of PSU-50.

At the second stage of tests, measurements of durability on a tension strength of samples of HWPC of the large-size sizes $(80 \times 80 \times 1600)$ and control models of comparison from a wooden bar of the same form on a four-dot bend in accordance with Russian State Standard 16483.12-72 have been taken. Tests were carried out at the stand with the hydraulic test BISS MAGNUM UT-05-3000 module. For a possibility of carrying out tests of samples of the above-stated sizes the industrial technological equipment which drawing is given in Figure 3 has been developed and has been made.
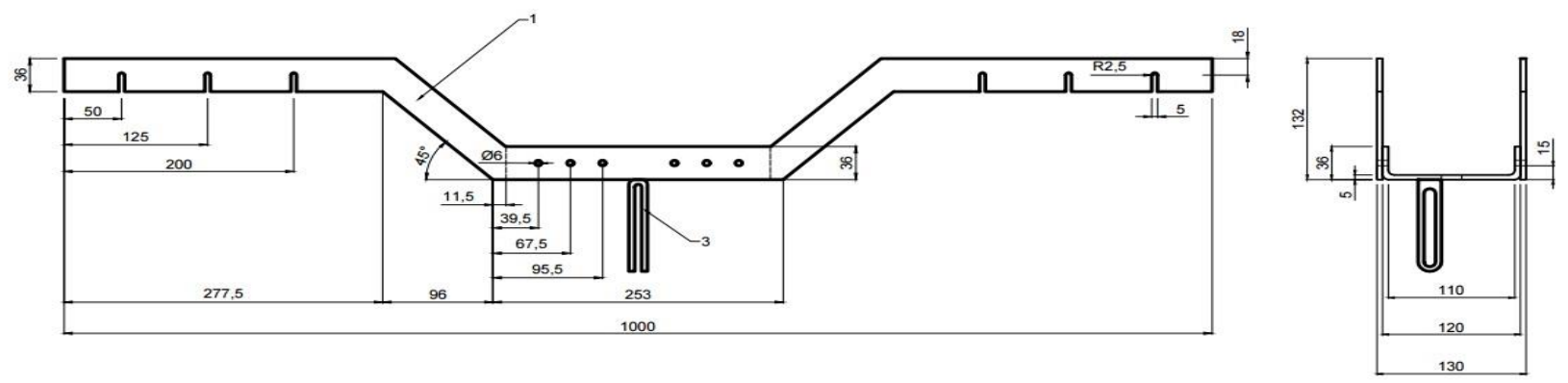

Figure 3. Drawing of the industrial technological equipment

The scheme of loading of the studied samples and pictures of test process are given in Figures 4 and 5 respectively.

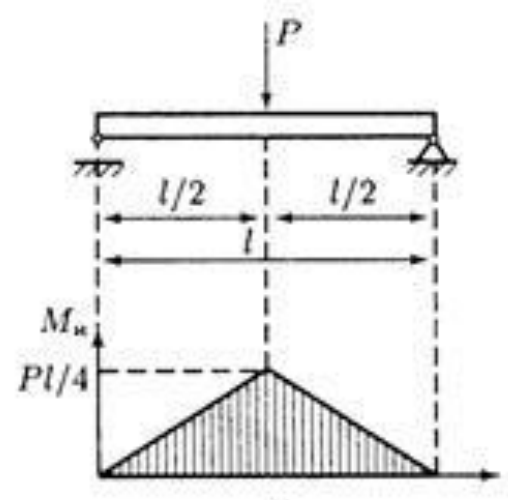

a

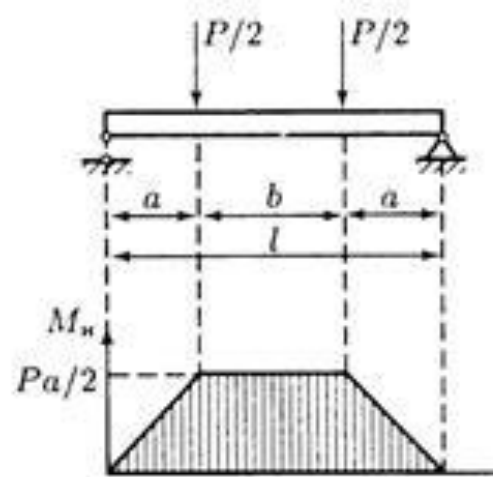

6

Figure 4. Schemes of loading of the samples at three - and a four-dot bend
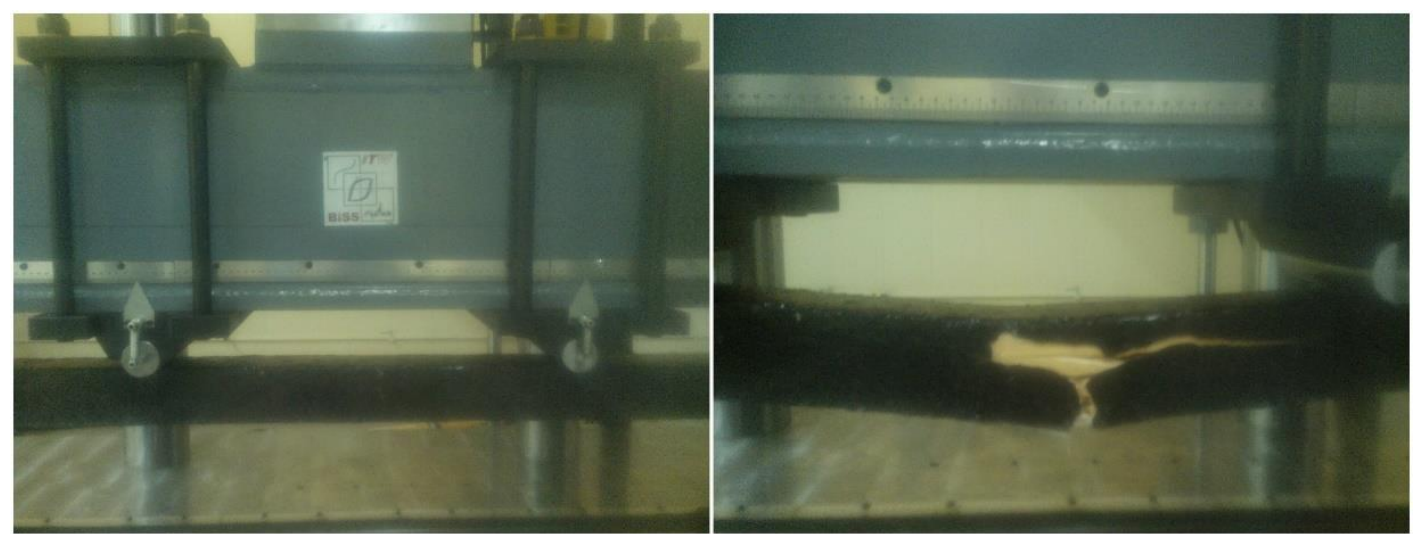

Figure 5. Tests of samples of HWPC and models of comparison by the sizes $80 \times 80 \times 1600$ 


\section{Results and Discussion}

Results of researches of the dependence of the durability of a polymeric matrix from the concentration of two types of the carbon micromodifiers entered into it structure are presented on the graphs (Figs. 6 and 7).

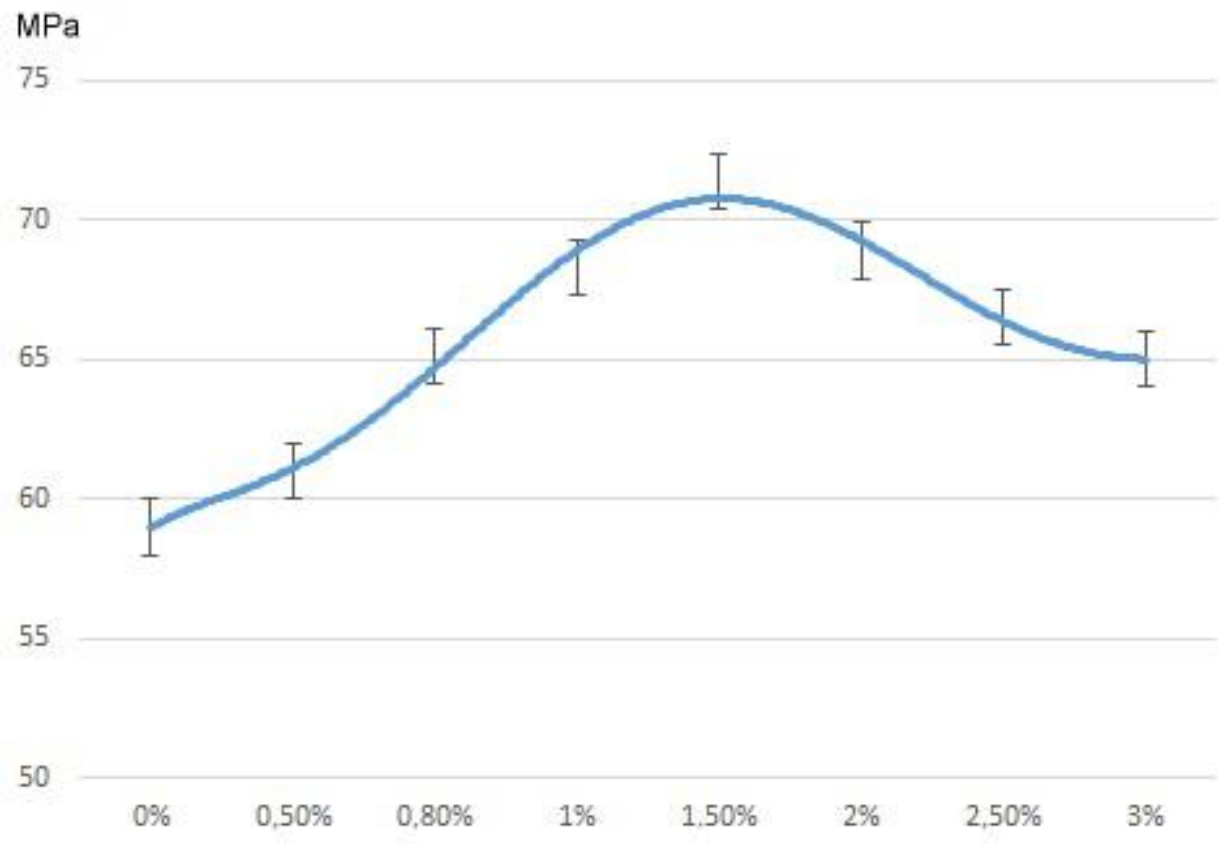

Figure 6. Dependence of the durability on the pressure strength of the test samples of epoxy polymer from the concentration of "Ugleron C"

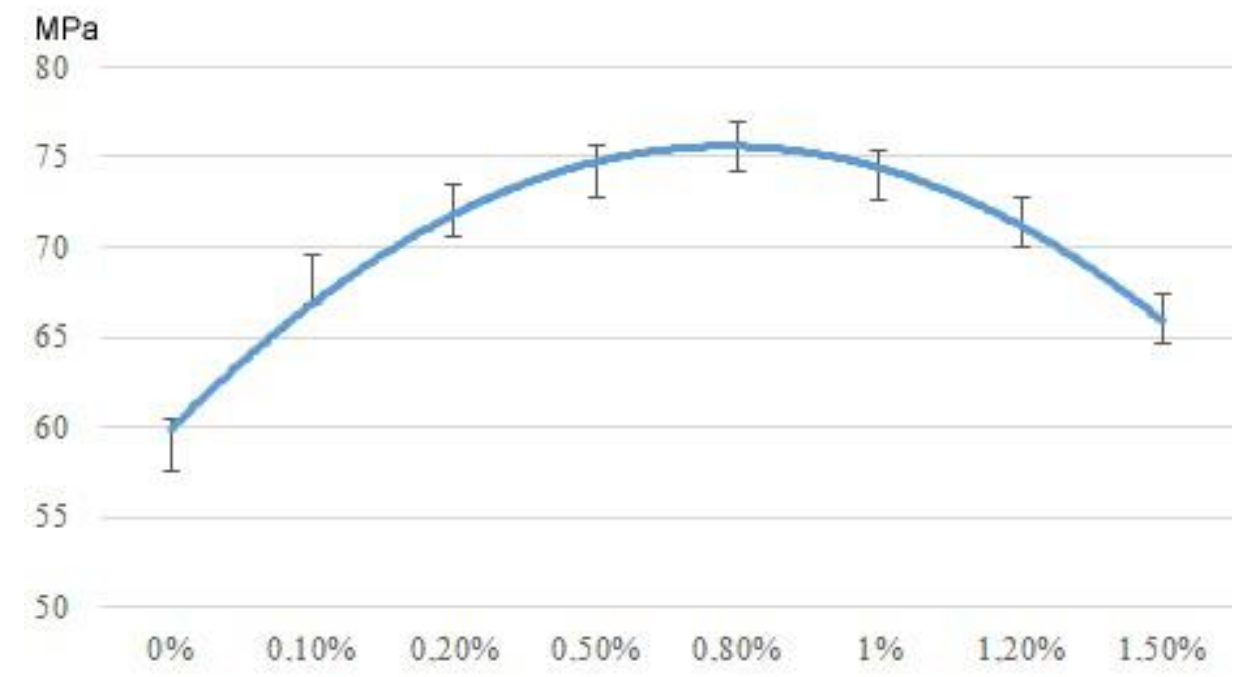

Figure 7. Dependence of durability on the pressure strength of the test samples epoxydean polymer from the concentration of the CNPMF

From the obtained data, it follows that optimal concentration for the entered sulfoadducts of carbon nanoclusters ("Ugleron C") are the values of $2 \%$ mass, relatively the mass of a hardener and $0.8 \%$ mass, for the CNPMF. The maximum values of increase of durability of samples of polymeric matrixes on pressure strength have made $21 \%$ and $31 \%$ respectively. According to the achieved results, the most effective type of micromodifier has been chosen and it was entered into composition for impregnation and into glue structure for vacuum formation of the strengthening HWPC of layers of T-25 (VMP) fabric-78 with a calico weave. 
Tests of small-sized samples (sizes of $20 \times 40 \times 800 \mathrm{~mm}$ ) have shown increase in durability at stretching at a bend on average for $100 \%$. Results of tests of full-scale samples (sizes $80 \times 80 \times 1600$ ) have shown increase in durability at a bend at $18 \%$ and increase in Young's modulus for $14 \%$.

Results of tests of the modified polymeric matrix and results of tests of samples of HWPC have been processed according to recommendations Russian State Standard 8.207-76 "Processing of results of measurements with repeated supervision" also correspond to values of the relative error of average values of these sizes which is not exceeding $5 \%$ at confidential probability 0.95 .

The analysis of results and studying of nature of samples destruction (Figure 8) show that at external reinforcing of wooden preparations by T-25 (VMP) fabric-78 the strengthening of the samples has practically not happened and observed increase in durability is caused only by resistance to destruction of an external "EpoxyPAN" membrane. It will be coordinated with the data of preliminary experiments on tests of the standard samples of wood beams and cubes (tested in accordance with Russian State Standard 16483.3-84) which were also strengthened by means of external membranes from "EpoxyPAN". It was founded early, that by using "EpoxyPAN" it is possible to increase the pressure strength of wooden details with the "EpoxyPAN" membrane more, than $60 \%$.

Thus, it is established that T-25 (VMP) fabric -78 with a calico weave is not priority material for use as material for the external reinforcing of extended wood preparations and production of highstrength HWPC. Strengthening of details full-strength fabrics can be recommended only for strengthening of details with isotropic properties (panels, boards, etc.).

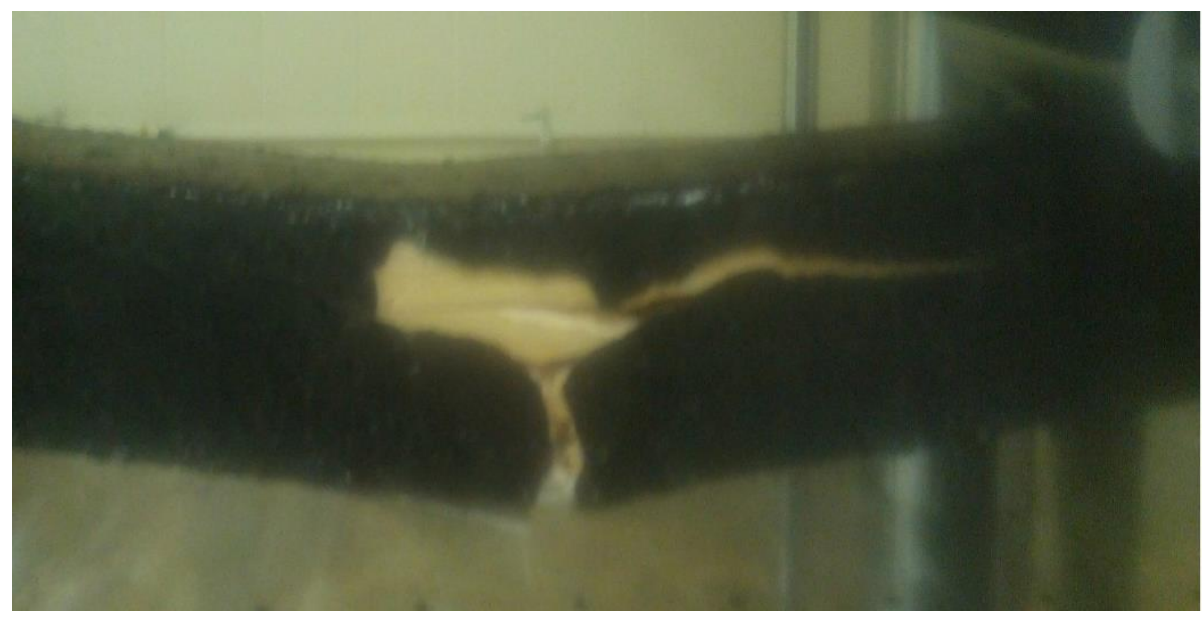

Figure 8. Nature of destruction of a sample of HWPC at limit loading by a four-dot method. Reinforcing fabric stretched, and the EpoxyPAN membrane collapsed

Such conclusion follows from the fact that when loading extended samples of HWPC the T-25 fabric firstly was extended and guided, without exerting at the same time impacts on mechanical properties of the extended parallel piped at his stretching (at a bend) and was broken off only when strength of a basis of HWPC has been already actually passed.

Thus, it is expedient to recommend use of the unidirectional tapes for strengthening of extended wooden beams, which are desirably high-strength carbon fibres.

It should be noted that, proceeding from nature of destruction of numerous samples of HWPC, on strength indicators strong impact is exerted by existence of knots and cracks on a wood basis, and also as already it has been stated above, its humidity.

The vast majority of the researchers [36-49] consider the HWPC are only the alternative to wooden details. We consider that the scope of the HWPC is much wider. And it can be applied in a number of tasks instead of fiberglass, carbon composites, metal etc.

The vast majority of the researchers consider also, that he more expensive cost of the HWPC in comparison with the wooden details hinder from it wide using [56]. But by our opinion, scope of the HWPC is not limited of the scope of the wooden details. HWPC are capable to replace metal, fiberglass, carbon composites and a coal plastic construction, whose costs are significantly higher, than the HWPC cost (Figure 1).

Comparatively with all the previous known results [36-57] it was founded now in this work, that the durability of the impregnated wood beams (for example) possible to be improved more, than $40 \%$ limit.

Ponomarev A.N., Rassokhin A.S. Hybrid wood-polymer composites in civil engineering. Magazine of Civil Engineering. 2016. No. 8. Pp. 45-57. doi: 10.5862/MCE.68.5 
Especially, if the external reinforcing will be made by the carbon tapes, the impregnation technology will include the CNPMF doping and the external EpoxyPAN membrane will be used together with all the other methods of improving the durability of the HWPC.

\section{Conclusions}

The analysis of literary data has shown that hybrid wood polymeric composites (HWPC) are the perspective materials in view of the acceptable level of their prime cost and potential durability, but demand the improvements of their physical and mechanical characteristics.

The pilot studies executed in the real work have shown that an effective method of increasing the general durability of HWPC is the modification of a polymeric matrix for the fiberglass and for the carbonplastic, the impregnating structure and glue compositions by the carbon micromodifiers sulfoadducts of the carbon nanoclusters ("Ugleron C") and carbon nanoporous microfibres (CNPMF).

It is established that in concentration dependences of durability of a polymeric matrix on the pressure strength from the mass number of carbon micromodifiers there are maxima: for sulfoadducts of the carbon nanoclusters - with $2 \%$ mass. relatively of the hardener mass, for CNPMF - with $0.8 \%$ mass. relatively of the hardener mass.

It is established that for epoxy polymeric compositions of impregnating structure and glue connections at their modification by means of sulfoadducts of nanoclusters of "Ugleron C" carbon and CNPMF increase of durability on the pressure strength respectively for $21 \%$ and for $31 \%$ is possible.

It is confirmed that drawing on a surface of HWPC of a continuous membrane from "EpoxyPAN" gives the increasing of the durability of the studied samples on stretching at a four-dot bend on average for $18 \%$ (and increasing the compressive strength for more than $60 \%$ ).

Together with the polymer matrix of composite reinforcing have been modified by CNPMF and "EpoxyPAN" coat, both method of improving the pressure and bending strength of the HWPC lead to 1.5 more time increasing the durability of the HWPC (against maximum $35 \%$, that was founded for improving the pressure strength in the works, early published [58])

It is defined that, achievement of the increased values of physical and mechanical properties of details from HWPC requires providing the following conditions and permission of the following tasks:

- use as material for external reinforcing of extended details from HWPC of the unidirectional highstrength carbon tapes or other high strength tapes. It will allow arising considerably the level of values of physical and mechanical characteristics of HWPC (together with the improved technology of impregnation of wood which has to increase wood resilience to bearing strain);

- the choice of structure of impregnation for the nanocomposite material "EpoxyPAN-primer" and for the main material "EpoxyPAN-coat", as protective membrane as they have successfully proved when carrying out tests of the studied test samples, and also thanks to their good compatibility with hydrophilic wood;

- working off the technology of compulsory gradient impregnation of wood preparations of HWPC by water-soluble and water compatible polymer structures, including research of methods of vacuum and ultrasonic impregnation. It will allow reaching the biggest hardness of near-surface layers of wood preparation, and also will allow avoiding too wide spacing of properties of the raw wood.

\section{Acknowledges}

Authors express profound gratitude to the Advisor of director general of JSC SIU "FIBREGLASS" Ph.D. V.I. Natrusov for the given methodical help and to the staff of test center SPSUACE for assistance in carrying out the tests.

\section{References}

1. U. S. Patent 0.942.809 Condensation product and method of making same.

2. Tehnicheskaja enciklopedija. Tom 2. [Technical encyclopedia. Vol. 2]. - Moscow: Akcionernoe Obshhestvo Sovetskaja jenciklopedija, 1927. 880 p. (rus)

3. Maas-Gees-teranus N.P. Vergleichsversuche an Holzschwellen, die mit Teer 61 Oder Basilit getrankt sind, Organ fur die Fortschritte des Eisenbahnwesens. H. 4,

\section{Литература}

1. U. S. Patent 0.942 .809 Condensation product and method of making same.

2. Техническая энциклопедия. Т. 2. М.: Акционерное общество Совесткая энциклопедияб 1927. 880 с.

3. Maas-Gees-teranus N.P. Vergleichsversuche an Holzschwellen, die mit Teer 61 Oder Basilit getrankt sind, Organ fur die Fortschritte des Eisenbahnwesens. H. 4,

Пономарев А.Н., Рассохин А.С. Гибридные древесно-полимерные композиты в строительстве // Инженерностроительный журнал. 2016. № 8(68). С. 45-57. 
München, 1924. $74 p$

4. Croitorua C., Patachia S., Lunguleasab A. New method of wood impregnation with inorganic compounds using ethy methylimidazolium chloride as carrier. Journal of Wood Chemistry and Technology. 2014. No. 11(35). Pp.113128.

5. Hiroyuki Y. Potential strength for resin-impregnated compressed wood. Journal of Materials Science Letters. 2001. Pp. 1127-1129.

6. Jenciklopedija polimerov [Encyclopedia of polymers]. Vol. 1. Moscow: Sovetskaja jenciklopedija, 1974. 1116 p. (rus)

7. Jenciklopedija polimerov [Encyclopedia of polymers] Vol. 2. Moscow: Sovetskaja jenciklopedija, 1974. 1034 p. (rus)

8. Jenciklopedija polimerov [Encyclopedia of polymers] Vol. 3. M.: Sovetskaja jenciklopedija, 1974. 1156 p.(rus)

9. Kancel'son M.J., Balaev G.A. Polimernye materialy [Polymeric materials]. Leningrad: Himija, 1982. 326 p. (rus)

10. Bracyhin E.A., Shul'gina Je.S. Tehnologija plasticheskih mass [Chemistry of plastic]. Leningrad: Himija, 1982. 134 p. (rus)

11. Kryzhanovskij V.K. Tehnicheskie svojstva polimernyh materialov [Technical properties of polymeric materials]. SPb: Professija, 2003. 240 p. (rus)

12. Trufakina L.M. Svojstva polimernyh kompozitov na osnove polivinilovogo spirta. [Properties of polymer composites on the basis polyvinyl alcohol]. Izvestija Tomskogo politehnicheskogo universiteta [News of TSPU]. 2014. Pp. 92-97. (rus)

13. Tugov I.I., Kostrykina G.I. Himija i fizika polimerov [Chemistry and physics of polymers]. Moscow: Himija, 1989. 432 p. (rus)

14. Sprenger S. Epoxy resins modified with elastomers and surface-modified silica nanoparticles. Polymer. 2013. No. 18(54). Pp. 4790-4797.

15. Pearson R., Liang Y. Polymer nanocomposites. Woodhead Publishing Ltd, 2010. Pp. 773-786.

16. Kim M., Park Y.B., Okoli O. I., Zhang C., Processing, characterization, and modeling of carbon nanotubereinforced multiscale composites. Composites Science and Technology. 2009. No. 3-4(69). Pp. 335-342.

17. Liao Y.H., Liang Z., Park Y.B., Wang B., Zhang C. Fabrication and Characterization of Carbon Nanotube/Glass Fiber-Reinforced Multiscale Composites. Proceeding of 47th AIAA/ASME/ASCE/AHS/ASC Structures, Structural Dynamics, and Materials Conference. 2006. Paper ID 1858.

18. Ronghui L., Liang F., Xinping L, Zhang S. Phenolic Resins Modified by Nanocopper Particles and their Service Performances. Polymer-Plastics Technology and Engineering. 2006. Pp. 1243-1249.

19. Kothmann M., Ziadeh M., Bakis G., Rios de Anda A., Breu $\mathrm{J}$, Altstädt $\mathrm{V}$. Analyzing the influence of particle size and stiffness state of the nanofiller on the mechanical properties of epoxy/clay nanocomposites using a nove shear-stiff nano-mica. Journal of Materials Science. 2015. Pp. 4845-4859.

20. Islam M.E., Mahdi T.H., Hosur M.V., Jeelani S. Characterization of carbon fiber reinforced epoxy composites modified with nanoclay and carbon nanotubes. Procedia Engineering. 2015. No. 105. Pp. 821-828.

21. Sahoo N., Rana S., Cho J., Li L., Chan S. Polymer nanocomposites based on functionalized carbon nanotubes. Prog. Polym. Sci. 2010. No. 35. Pp. 837-867.

22. Singh B., Singh D., Mathur R., Dhami T. Influence of surface modified MWCNTs on the mechanical, electrical and thermal properties of polyimide nanocomposites. Nanoscale Res. Lett. 2008.
München, 1924. $74 \mathrm{p}$

4. Croitorua C., Patachia S., Lunguleasab A. New method of wood impregnation with inorganic compounds using ethyl methylimidazolium chloride as carrier // Journal of Wood Chemistry and Technology. 2014. № 11(35). Pp. 113-128.

5. Hiroyuki Y. Potential strength for resin-impregnated compressed wood. Journal of Materials Science Letters. 2001. Pp. 1127-1129.

6. Энциклопедия полимеров. Т. 1. М.: Советская энциклопедия, 1974. $1116 \mathrm{c.}$

7. Энциклопедия полимеров. Т. 2. М.: Советская энциклопедия, 1974. 1116 с.

8. Энциклопедия полимеров. Т. 3. М.: Советская энциклопедия, 1974. 1116 с.

9. Кацнельсон М.Ю., Балаев Г.А. Полимерные материалы. Л.: Химия, 1982. 326 с.

10. Брацихин Е.А., Шульгина Э.. Технология пластических масс. Л.: Химия, 1982. 134 с.

11. Крыжановский В.К. Технические свойства полимерных материалов. СПб: Профессия, 2003. 240 с.

12. Труфракина Л.М. Свойства полимерных композитов на основе поливинилового спирта. Известия Томского политехнического университета. 2014. С. 92-97.

13. Тугов И.И., Кострыкина Г.И. Химия и фиизика полимеров. М.: Химия, 1989. 432 с.

14. Sprenger S. Epoxy resins modified with elastomers and surface-modified silica nanoparticles // Polymer. 2013. № 18(54). Pp. 4790-4797.

15. Pearson R., Liang Y. Polymer nanocomposites. Woodhead Publishing Ltd, 2010. Pp. 773-786.

16. Kim M., Park Y.B., Okoli O. I., Zhang C., Processing, characterization, and modeling of carbon nanotubereinforced multiscale composites // Composites Science and Technology. 2009. № 3-4(69). Pp. 335-342.

17. Liao Y.H., Liang Z., Park Y.B., Wang B., Zhang C. Fabrication and Characterization of Carbon Nanotube/Glass Fiber-Reinforced Multiscale Composites. Proceeding of 47th AIAA/ASME/ASCE/AHS/ASC Structures, Structural Dynamics, and Materials Conference. 2006. Paper ID 1858.

18. Ronghui L., Liang F., Xinping L, Zhang S. Phenolic Resins Modified by Nanocopper Particles and their Service Performances // Polymer-Plastics Technology and Engineering. 2006. Pp. 1243-1249.

19. Kothmann M., Ziadeh M., Bakis G., Rios de Anda A., Breu $\mathrm{J}$, Altstädt $\mathrm{V}$. Analyzing the influence of particle size and stiffness state of the nanofiller on the mechanical properties of epoxy/clay nanocomposites using a nove shear-stiff nano-mica // Journal of Materials Science. 2015. Pp. 4845-4859.

20. Islam M.E., Mahdi T.H., Hosur M.V., Jeelani S. Characterization of carbon fiber reinforced epoxy composites modified with nanoclay and carbon nanotubes // Procedia Engineering. 2015. № 105. Pp. 821-828.

21. Sahoo N., Rana S., Cho J., Li L., Chan S. Polymer nanocomposites based on functionalized carbon nanotubes // Prog. Polym. Sci. 2010. № 35. Pp. 837-867.

22. Singh B., Singh D., Mathur R., Dhami T. Influence of surface modified MWCNTs on the mechanical, electrical and thermal properties of polyimide nanocomposites // Nanoscale Res. Lett. 2008.

23. Kostopoulos V., Baltopoulos A., Karapappas P., Vavouliotis A., Paipetis A. Impact and after-impact properties of carbon fibre reinforced composites enhanced with multi-wall carbon nanotubes // Compos. Sci. Technol. 2010. № 70. Рp. 553-563.

24. Пономарев А.Н. Высококачественные бетоныю Анализ возможностей и практика использования методов нанотехнологий / Инженерно-строительный журнал.

Ponomarev A.N., Rassokhin A.S. Hybrid wood-polymer composites in civil engineering. Magazine of Civil Engineering. 2016. No. 8. Pp. 45-57. doi: 10.5862/MCE.68.5 
23. Kostopoulos V., Baltopoulos A., Karapappas P., Vavouliotis A., Paipetis A. Impact and after-impact properties of carbon fibre reinforced composites enhanced with multi-wall carbon nanotubes. Compos. Sci. Technol. 2010. No. 70. Pp. 553-563.

24. Ponomarev A.N. Vysokokachestvennye betony. Analiz vozmozhnostej i praktika ispol'zovanija metodov nanotehnologii [High-quality concrete. Analysis and practice of use of methods of nanotechnologies]. Magazine of Civil Engineering. 2009. No.6. Pp. 25-33. (rus)

25. Azeez A.A., Rhee K.Y., Park S. J., Hui D. Epoxy clay nanocomposites - processing, properties and applications: a review. Compos. Part B Eng. 2013. No. 45. Pp. 308320.

26. Plevris N., Triantafillou T. Time-dependent behavior of RC members strengthened with FRP laminates. Journal of Structural Engineering. 1994. No. 120. Pp. 1016-1042.

27. Biblis E.J. Analysis of wood-fiber glass composite beams within and beyond the elastic region. Forest Prod. J. 1965. No. 2(15). Pp. 81-88.

28. Triantafillou T., Deskovic N. Prestressed FRP sheets as external reinforcement of wood members. Journal of Structural Engineering, ASCE. 1992. Vol. 118. No. 5. Pp. 1270-1284.

29. Plevris N., Triantafillou T. Creep behavior of FRPreinforced wood members. Journal of Structural Engineering. 1995. No. 121(2). Pp. 174-186.

30. Triantafillou T. Shear reinforcement of wood using FRP materials. Journal of Materials in Civil Engineering. 1997. No. 9. Pp. $65-69$.

31. Dagher H.J. High-performance wood composites for construction. VII EBRAMEM, São Carlos - Brasil. 2000. Pp. 154-163.

32. Tingley D., Cegelka S. High-strength-fiber-reinforced plastic reinforced wood. Internacional Wood Engineering Conference. New Orleans, Lousiana, USA. 1996. Vol. 3. Pp. 57-64.

33. Dempsey D., Scott D. Wood members strengthened with mechanically fastened FRP strips. Journal of Composites for Construction. 2006. No. 10. Pp. 392-398.

34. Andor K., Lengyel A., Polgár R., Fodor T., Karácsonyi Z. Experimental and statistical analysis of spruce timber beams reinforced with CFRP fabric. Construction and Building Materials. 2015. Vol. 99. Pp. 200-207.

35. Akbiyik A., Lamanna A.J., Hale W.M. Feasibility investigation of the shear repair of timber stringers with horizontal splits. Construction and Building Materials. 2007. Vol. 21. No. 5. Pp. 991-1000.

36. De Lorenzis L., Stratford T., Hollaway L. Structurally deficient civil engineering infrastructure: concrete, metallic, masonry and timber structures. Strengthening and Rehabilitation of Civil Infrastructures Using FibreReinforced Polymer (FRP) Composites. 2008. Pp. 1-44.

37. Nowak T. Analiza pracy statycznej zginanych belek drewnianych wzmacnianych przy użyciu cfrp [Analysis of static work of bent wood beams reinforced with CFRP]: Praca doktorska T. Nowak; dr hab. inż. J. Jasieńko; Politechnika Wrocławska Instytut Budownictwa. Wrocław [Wrocław University of Science and Technology], 2007. $190 \mathrm{p}$.

38. Canning L., Luke S. Flexural strengthening application of fibre-reinforced polymer (FRP) plates. Strengthening and Rehabilitation of Civil Infrastructures Using FibreReinforced Polymer (FRP) Composites. 2008. Pp. 267291.

39. Kricin A.V., Utochkina E.S., Lobov D.M., Tihonov A.V. Ocenka prochnosti i deformativnosti obrazcov sostavnyh derevjannyh balok, objedinennyh uglerodnoj lentoj [Assessment of durability and defformativnost of samples of the compound wooden beams united by a carbon tape].
2009. № 6. C. 25-33.

25. Azeez A.A., Rhee K.Y., Park S. J., Hui D. Epoxy clay nanocomposites - processing, properties and applications: a review // Compos. Part B Eng. 2013. № 45. Pp. 308320.

26. Plevris N., Triantafillou T. Time-dependent behavior of RC members strengthened with FRP laminates // Journal of Structural Engineering. 1994. № 120. Pp. 1016-1042.

27. Biblis E.J. Analysis of wood-fiber glass composite beams within and beyond the elastic region // Forest Prod. J. 1965. № 2(15). Pp. 81-88.

28. Triantafillou T., Deskovic N. Prestressed FRP sheets as external reinforcement of wood members // Journal of Structural Engineering, ASCE. 1992. № 5(118). Pp. 1270 1284.

29. Plevris N., Triantafillou T. Creep behavior of FRPreinforced wood members // Journal of Structural Engineering. 1995. № 121(2). Pp. 174-186.

30. Triantafillou T. Shear reinforcement of wood using FRP materials // Journal of Materials in Civil Engineering. 1997. № 9. Pp. 65-69.

31. Dagher H.J. High-performance wood composites for construction // VII EBRAMEM, São Carlos - Brasil. 2000. Pp. 154-163.

32. Tingley D., Cegelka S. High-strength-fiber-reinforced plastic reinforced wood // Internacional Wood Engineering Conference. New Orleans, Lousiana, USA. 1996. Vol. 3. Pp. 57-64.

33. Dempsey D., Scott D. Wood members strengthened with mechanically fastened FRP strips // Journal of Composites for Construction. 2006. № 10. Pp. 392-398.

34. Andor K., Lengyel A., Polgár R., Fodor T., Karácsonyi Z. Experimental and statistical analysis of spruce timber beams reinforced with CFRP fabric // Construction and Building Materials. 2015. Vol. 99. Pp. 200-207.

35. Akbiyik A., Lamanna A.J., Hale W.M. Feasibility investigation of the shear repair of timber stringers with horizontal splits // Construction and Building Materials. 2007. № 5 (21). Pp. 991-1000.

36. De Lorenzis L., Stratford T., Hollaway L. Structurally deficient civil engineering infrastructure: concrete, metallic masonry and timber structures // Strengthening and Rehabilitation of Civil Infrastructures Using FibreReinforced Polymer (FRP) Composites. 2008. Pp. 1-44.

37. Nowak T. Analiza pracy statycznej zginanych belek drewnianych wzmacnianych przy użyciu cfrp [Analysis of static work of bent wood beams reinforced with CFRP] Praca doktorska T. Nowak; dr hab. inż. J. Jasieńko Politechnika Wrocławska Instytut Budownictwa. Wrocław [Wrocław University of Science and Technology], 2007. $190 \mathrm{p}$.

38. Canning L., Luke S. Flexural strengthening application of fibre-reinforced polymer (FRP) plates // Strengthening and Rehabilitation of Civil Infrastructures Using FibreReinforced Polymer (FRP) Composites. 2008. Pp. 267291.

39. Кричин А.В., Уточкина Е.С., Лобов Д.М., Тихонов А.В. Оценка прочности и десоормативности образцов составныхх деревянных балок, объединенных углеродной лентой // Приволжский научный журнал. 2013. № 2(26). C. 7-13.

40. Morales-Conde M., Rodríguez-Liñán C., Rubio-de Hita P. Bending and shear reinforcements for timber beams using GFRP plates. Construction and Building Materials. 2015. Vol. 96. P. 461-472.

41. Davids W., Nagy E., Richie M. Fatigue behavior of composite-reinforced glulam bridge girders // Journal of Bridge Engineering. 2008. Vol. 13. № 2. Pp. 183-191.

42. Fiorelli J., Dias A.A. Analysis of the strength and stiffness of timber beams reinforced with carbon fiber and glass

Пономарев А.Н., Рассохин А.С. Гибридные древесно-полимерные композиты в строительстве // Инженерностроительный журнал. 2016. № 8(68). С. 45-57. 
Privolzhsky Scientific Journal. 2013. No. 2(26). Pp. 7-13. (rus)

40. Morales-Conde M., Rodríguez-Liñán C., Rubio-de Hita P. Bending and shear reinforcements for timber beams using GFRP plates. Construction and Building Materials. 2015. Vol. 96. P. 461-472.

41. Davids W., Nagy E., Richie M. Fatigue behavior of composite-reinforced glulam bridge girders. Journal of Bridge Engineering. 2008. Vol. 13. No. 2. Pp. 183-191.

42. Fiorelli J., Dias A.A. Analysis of the strength and stiffness of timber beams reinforced with carbon fiber and glass fiber. Materials Research. 2003. Vol. 6. No. 2. Pp. 193202.

43. Kliger I.R., Haghani R., Brunner M., Harte A.M., Schober K.-U. Wood-based beams strengthened with FRP laminates: improved performance with pre-stressed systems. European Journal of Wood and Wood Products. 2016. Vol. 74. No. 3. Pp. 319-330.

44. Barreto A.M.J.P., Campilho R.D.S.G, De Moura M.F.S.F, Morais J.J.L., Santos C.L. Repair of wood trusses loaded in tension with adhesively bonded carbon-epoxy patches. The Journal of Adhesion. 2010. Vol. 86. No. 5-6. Pp. 630648.

45. Chang W.-S. Repair and reinforcement of timber columns and shear walls - A review. Construction and Building Materials. 2015. Vol. 97. Pp. 14-24.

46. Schober K.U. Innovative Timber Composites - Improving Wood with Other Materials. Bath, UK: Schober, K.U. (ed.), University of Bath, 2013. 48 p.

47. Lobov D.M., Kricin A.V., Tihonov A.V. Osobennosti armirovanija derevjannyh elementov, usilennyh uglerodnym voloknom, pri staticheskom izgibe [Features of reinforcing of the wooden elements strengthened by carbon fiber]. Izvestija KGASU. 2013. No. 2(24). Pp. 132138. (rus)

48. Yahyaei-Moayyed M., Taheri F. Experimental and computational investigations into creep response of AFRP reinforced timber beams. Composite Structures. 2011. Vol. 93. No. 2. Pp. 616-628.

49. Davalos J.F., Kim Y., Barbero E.J. A layerwise beam element for analysis of frames with laminated sections and flexible joints. Finite Elements in Analysis and Design. 1995. Vol. 19. No. 3. Pp. 181-194.

50. Dolan C.W., Galloway T.L., Tsunemori A. Prestressed glued-laminated timber beam-pilot study. Journal of Composites for Construction. 1997. Vol. 1. No. 1. Pp. 1016.

51. Nadir Y., Nagarajan P., Ameen M., Arif M M. Flexural stiffness and strength enhancement of horizontally glued laminated wood beams with GFRP and CFRP composite sheets. Construction and Building Materials. 2016. Vol. 112. Pp. 547-555.

52. Franke S., Franke B., Harte A. Failure modes and reinforcement techniques for timber beams - State of the art. Construction and Building Materials. 2015. Vol. 97. Pp. 2-13.

53. Svecova D., Eden R.J. Flexural and shear strengthening of timber beams using glass fibre reinforced polymer bars an experimental investigation. Canadian Journal of Civil Engineering. 2004. Vol. 31. No. 1. Pp. 45-55.

54. Negrão J. Preliminary study on wire prestressing methods for timber pieces' reinforcement. Construction and Building Materials. 2016. Vol. 102. Pp. 1093-1100.

55. Taheri F., Nagaraj M., Khosravi P. Buckling response of glue-laminated columns reinforced with fiber-reinforced plastic sheets. Composite Structures. 2009. Vol. 68. No. 3. Pp. 481-490.

56. Kim Y.J., Harries K.A. Modeling of timber beams strengthened with various CFRP composites. Engineering Structures. 2010. Vol. 32. No. 10. Pp. 3225-3234. fiber // Materials Research. 2003. № 2(6). Pp. 193-202.

43. Kliger I.R., Haghani R., Brunner M., Harte A.M., Schober K.-U. Wood-based beams strengthened with FRP laminates: improved performance with pre-stressed systems // European Journal of Wood and Wood Products. 2016. № 3(74). Pp. 319-330.

44. Barreto A.M.J.P., Campilho R.D.S.G, De Moura M.F.S.F Morais J.J.L., Santos C.L. Repair of wood trusses loaded in tension with adhesively bonded carbon-epoxy patches // The Journal of Adhesion. 2010. № 5-6(86). Pp. 630-648.

45. Chang W.-S. Repair and reinforcement of timber columns and shear walls - A review // Construction and Building Materials. 2015. Vol. 97. Pp. 14-24.

46. Schober K.U. Innovative Timber Composites - Improving Wood with Other Materials. Bath, UK: Schober, K.U. (ed.), University of Bath, 2013. $48 \mathrm{p}$.

47. Лобов Д.М., Кричин А.В., Тихонов А.В. Особенности армирования деревянных элементов, усиленных углеродным волокном, пристатическом изгибе // Известия КГАСУ. 2013. № 2(24). С. 132-138.

48. Yahyaei-Moayyed M., Taheri F. Experimental and computational investigations into creep response of AFRP reinforced timber beams // Composite Structures. 2011. № 2(93). Pp. 616-628.

49. Davalos J.F., Kim Y., Barbero E.J. A layerwise beam element for analysis of frames with laminated sections and flexible joints // Finite Elements in Analysis and Design. 1995. № 3(19). Pp. 181-194.

50. Dolan C.W., Galloway T.L., Tsunemori A. Prestressed glued-laminated timber beam-pilot study // Journal of Composites for Construction. 1997. № 1(1). Pp. 10-16.

51. Nadir Y., Nagarajan P., Ameen M., Arif M M. Flexural stiffness and strength enhancement of horizontally glued laminated wood beams with GFRP and CFRP composite sheets // Construction and Building Materials. 2016. Vol. 112. Pp. 547-555.

52. Franke S., Franke B., Harte A. Failure modes and reinforcement techniques for timber beams - State of the art // Construction and Building Materials. 2015. Vol. 97. Pp. 2-13.

53. Svecova D., Eden R.J. Flexural and shear strengthening of timber beams using glass fibre reinforced polymer bars an experimental investigation // Canadian Journal of Civil Engineering. 2004. Vol. 31. № 1. Pp. 45-55.

54. Negrão J. Preliminary study on wire prestressing methods for timber pieces' reinforcement // Construction and Building Materials. 2016. Vol. 102. Pp. 1093-1100.

55. Taheri F., Nagaraj M., Khosravi P. Buckling response of glue-laminated columns reinforced with fiber-reinforced plastic sheets // Composite Structures. 2009. Vol. 68. № 3. Pp. 481-490.

56. Kim Y.J., Harries K.A. Modeling of timber beams strengthened with various CFRP composites // Engineering Structures. 2010. Vol. 32. № 10. Pp. 32253234.

57. Deka M., Saikia C.N. Chemical modification of wood with thermosetting resin: effect on dimensional stability and strength property // Bioresource Technology. 2000. Vol. 73. № 2. Pp. 179-181.

58. Moore G.R., Kline D.E., Blankenhorn P.R. Impregnation of wood with a high viscosity epoxy resin // Wood Fiber Sei. 1983. Vol. 15. № 3. Pp. 223-234.

59. Resoltech. Water based Epoxy Resin. [Электронный pecypc]. Сист. требования:AdopeAcrobatReader. URL: http://www.resoltech.com/IMG/pdf/DS-1010_V2.pdf (дата обращения: 10.11.2016)

60. Пат. 2478117 Российская Федерация, МПК С10С 3/04 C04B 24/16, C04B 24/36, A61K 31/095, A61P 31/12, В82Y 5/00, В82Y 30/00, В82Y 40/00. Сульфооаддукт нанокластеров углерода и способ его получения /

Ponomarev A.N., Rassokhin A.S. Hybrid wood-polymer composites in civil engineering. Magazine of Civil Engineering. 2016. No. 8. Pp. 45-57. doi: 10.5862/MCE.68.5 
57. Deka M., Saikia C.N. Chemical modification of wood with thermosetting resin: effect on dimensional stability and strength property. Bioresource Technology. 2000. Vol. 73. No. 2. Pp. 179-181.

58. Moore G.R., Kline D.E., Blankenhorn P.R. Impregnation of wood with a high viscosity epoxy resin. Wood Fiber Sei. 1983. Vol. 15. No. 3. Pp. 223-234.

59. Resoltech. Water based Epoxy Resin. [Electronic Resource]. System requirements:AdopeAcrobatReader. URL: http://www.resoltech.com/IMG/pdf/DS-1010_V2.pdf (date of reference: 10.11.2016).

60. Ponomarev A.N., Judovich M.E., Kozeev A.A. Sul'foaddukt nanoklasterov ugleroda i sposob ego poluchenija [Sulfoadduct of nanoclusters of carbon and way of his receiving]. Patent Russia no. 2478117, 2013. (rus)

61. Ponomarev A.N. Nanoporistoe uglerodnoe mikrovolokno dlja sozdanija radiopogloshhajushhih materialov [Nanoporous carbon microfiber for creation of the radiosorption materials]. Patent Russia no. 2570794, 2014. (rus)

\section{Andrey Ponomarev,}

+7(911)9293522; 9293522@gmail.com

\section{Aleksandr Rassokhin, +7(911)5266859; melavi1@rambler.ru}

Пономарев А.Н., Юдович М.Е., Козеев А.А.; заявитель и патентообладатель Пономарев А.Н № 2010105074/04; заявл. 08.02.10; опубл. 23.03.13.

61. Пат. 2570794 Российская Федерация, МПК Н01Q 17/00, Н05K 9/00. Нанопористое углеродное микроволокно для создания радиопоглощающих материалов / Пономарев А.Н.; заявитель и патентообладатель Пономарев А.Н. - № 2014151923/07; заявл. 23.12.14 опубл. 10.12.15.
Андрей Николаевич Пономарев, +7(911)9293522;

эл. почта: 9293522@gmail.com

Александр Сергеевич Рассохин, +7(911)5266859; эл. почта: melavi1@rambler.ru

(c) Ponomarev A.N., Rassokhin A.S., 2016

Пономарев А.Н., Рассохин А.С. Гибридные древесно-полимерные композиты в строительстве // Инженерностроительный журнал. 2016. № 8(68). С. 45-57. 